\title{
The Reception of the Indian Thought by the Culture and Art of Europe of the 20th Century*
}

\author{
Ludmila Kryshtop \\ History of Philosophy Department \\ Peoples' Friendship University of Russia \\ 6 Miklukho-Maklaya Str. \\ Moscow, Russia \\ E-mail: kryshtop_le@rudn.university
}

\author{
Ruzana Pskhu \\ History of Philosophy Department \\ Peoples' Friendship University of Russia \\ 6 Miklukho-Maklaya Str. \\ Moscow, Russia \\ E-mail: r.pskhu@mail.ru
}

\begin{abstract}
The interest to the Indian spiritual heritage has been increasing since Europe has opened India at the Age of Early Enlightenment. In the Indian way of thinking, the thinkers used to see a source for renovation of the European spiritual culture. The ideas of the Indian world view give European culture and arts a supplement, a possibility to rebuild an integral wholeness. At the same time, it helps Europeans to see the world in a different way, to describe it in different terms that receives a new life and intellectual experience, prompts to go out the boundaries of own culture. The article concerns some figures of European Culture of the 20th century attached importance to analyzing of the Indian thought. It also describes some trends in development of European literature of this period connected with reception of the Indian spiritual heritage. The elemenets and terms of the Indian Philosophy, involved into the artistic process of creation of the literary images by Hermann Hesse, are the key-objects of the analysis in this paper. The passage of the famous novel "Das Glasperlenspiel", named as "Indischer Lebenslauf", describing the life of Dasa, is based on the crucial patterns of Vedanta philosophy.
\end{abstract}

Keywords-Indian thought; European Culture and Art; Jaspers; Jung; spiritual culture; evolution; crisis; Hesse; Glasperlenspiel; Vedanta; maya

Die Würde und Größe seiner Gestalt, das Licht von innen her, in welchem sein Antlitz strahlte, die Sammlung und eherne Unanfechtbarkeit in seinen Zügen sandten Wellen und Strahlen aus, in deren Mitte er thronte wie ein Mond, und die angehäufte Geisteskraft, der still gesammelte Wille in seiner Erscheinung spann einen solchen Zauberkreis um ihn, daß man wohl spürte:

dieser Mann vermöchte mit einem bloßen Wunsch und Gedanken, ohne auch nur den Blick zu erheben, einen zu töten und wieder ins Leben zurückzurufen. Hermann Hesse. Das Glasperlenspiel

\section{INTRODUCTION}

The citation used as the epigraph to our article is a good image of the Indian culture as it perceived by the European

* The Paper is made with the support of Russian Science Foundation. The Project is "Indian Philosophy in the History of World Philosophy Context: the Meanings’ Translation Problem” № 16-18-10427. eyes. Since Indian thought has been opened for Europeans at the Age of Early Enlightenment, the interest for this subject matter has never been quenching. The Indian world view is in some aspects quite different to the European one. That is why the more detailed analysis of Indian spiritual heritage and its better understanding was always considered by the European thinkers as a source of ideas can be used for renovation of Europe, for getting out of spiritual and intellectual crisis Europe was living in. Through it was quite often inherent for European philosophers (and we can trace it even now) to undervalue the Indian way of thinking in prioritizing the rationality of Modern Europe that did not take place in East thinking model as a whole and in Indian one in particular. But we also find European thinkers seeing in India a potential which is needed in order to get out of intellectual crisis and open a new horizon of spiritual evaluation. The other aspect of European interest to the Indian Philosophy was materialized in the literature. The most famous of the European writers of the 20th century, whose name usually is connected with India and its culture, is the German writer Hermann Hesse (1877-1962), the author of some novels based on Indian narratives and patterns of thinking. The literary works of $\mathrm{H}$. Hesse show the deep interest and multidimensional reception of Indian philosophy into the European intellectual culture of the 20th century.

\section{KARL GUSTAV JUNG AND HIS VIEWS ON INDIAN SPIRITUAL CULTURE}

The first thinker we shall consider in this context is Karl Gustav Jung (1875-1961). Indian thought which Jung turned to was one of important sources of his own philosophical views. Unfortunately, he is often undervalued as philosopher, for we use to consider him at the first extant as an analytic psychologist and to miss a great importance which the philosophical base had for his psychological activity. Jung did not only analyze the psychological problems contemporary men and women had to deal with, but also tried to consider them in context of the structure of psyche, of the way contemporary human being looked at the world. In the middle point of his analyzes stand Europeans. But in trying to understand better their psychical constitution and to find the way it is possible to help Europeans to get out of the 
crisis, Jung turned to spiritual heritage of India which he considered in terms of his psychological theory.

Jung distinguished two types of psychical structures. One of them is rational, another is intuitional. He carried out the comparing of European and Indian world outlook with the help of these terms. The notion of maya plays an important role for Indian thought. Jung interpreted maya as a part of psyche which is usually depressed in Europeans and can be revealed only through dreaming. That is an effect of the split the pagan Europe has run into confronted with higher spirituality of monotheistic religion of Christianity. As a result, we get a situation nearly identical with situation of Negros in Africa when they met the higher civilization of Europe. Africa has stopped in his inner spiritual evolution and so did Europe in the first centuries of Christianity. This new spirituality was very good and perhaps also too good for Europe at that time. This spiritual conflict between external foreign spirituality and inner level of spiritual evolution has caused psyche of Europeans has been broken into two parts namely conscious (rational) and unconscious (irrational). The first identified itself with Christian spirituality which became more and more rational in length of time. The second part absorbed all the features of old pagan mentality and has been deeply depressed by the first one1. In European culture, it reflected as confrontation of reason and faith, science and religion, rationality and irrationality. The individual in Europe is disintegrated. $\mathrm{He}$ has lost the connection with his own roots and so has also lost himself. This situation of permanent depressing is considered by Jung as dangerous. It cannot go on through and through. It needs a kind of compensation. That is why we find in European history that the periods of scientific and technical increasing were always connected or replaced with the spiritual crisis in forms of later religious fanaticism or contemporary secularization. In further, it can lead Europeans to even more destructive consequences such as renewal bacchanalias of depressing pagan nature 2 . In purpose to find the way Europeans can get out of this spiritual crisis Jung turned to Indian thought which reflects according to him the different kind of evaluation [2].

In the Indian world outlook there is no such problem as inner split into conscious and unconscious. There is also no feeling of isolation from nature. The individual human being in India is not only his mind, but also the whole body with its natural feelings and requirements. His unconscious nature is not depressed and so has not to use each opportunity to escape, to break conscious defense. In Indian conscious and unconscious parts create an integral wholeness. A human being exists in peace and tranquility. But this way of evaluation has also disadvantages. At least from the

Another analytical psychologist Erich Fromm considered this spiritual situation in the other terms. He distinguished between inner (hidden) religion and external (official) religion. According to Fromm Christianity with his exhortation to love and self-renunciation for Europe was and is only this external religion, the inner one stays until nowadays barbarism with its values of power, richness, win and so on [1].

The historical development proved Jung's right in this regard, as the political ideologies of XXth centuries can be considered as form of such compensation.
European point of views. At first, we cannot tell about real historical progress in regard of Indian culture. The Indian world is the world of monotone endless reiteration. That is kind of anonym, impersonal existence, constant immutable run of birth and death. There is nothing that had not already existed in the past. It finds a perfect reflection in idea of reincarnation circle. And with whole right it can be stated this idea could arise only in Indian unhistorical world view. As a result, lack of depressing of unconscious part of psyche causes the unconscious Europeans deal only in dreams with is in India available, perceptible in ordinary life. That is why Europeans coming to India feel themselves as if they fall into a dream world. All things seem to them to be an illusion, to be unreal. An in the fact we meet an absolutely inverted world in India. What we consider as reality becomes here unreal, and what is for us invisible and unreal is here a truly reality [3].

However, Jung was far from assertion Europeans need to adopt Indian world views. Actually, he held it up as impossible. That kind of world feeling is so foreign for Europe that European cannot also comprehend it correctly. Europeans consider Indian thought and Indian spiritual practices in terms of European way of thinking and so Indian heritage becomes in Europe an instrument, means for achievement of higher level of spiritual evolution connected in Europe with depressing of unconscious or just a new religion. Howbeit it loses its own nature and is after that unable to lead a human being to inner integrity.

\section{KARL JASPERS AND CONTRIBUTION OF INDIAN PHILOSOPHY AND ART TO AXIAL AGE}

Jung has contributed much in process of mastering and oncoming of Indian spiritual heritage. He showed the way it can be useful for European men and women in their inner evaluation, but we must also to stay there are remnants of eurocentrism in his thought. For instance, Jung supposed that an Indian as far as he is truly an Indian does not think. He rather observes that we can determine as a thought or thinking process. In this aspect Jung regarded a feature that affiliates Indian world view with the one of primitive society. It seems Jung misjudges herewith perhaps just unconsciously the Indian cultural tradition. But this kind of interpretation of Indian spiritual heritage was not the only one we find in European intellectual space in the 20th century. Another thinker we turn to is Karl Theodor Jaspers. As Jung he was also a practicing psychologist, but unlike Jung he is better known as a philosopher. In analyzing the world view structure of contemporary human being he emphasized a time period which has been named as axial age and continued from about the 18 th century until the 2 nd century B.C. According to Jaspers, in that time, the new way of thinking based on ideas of infinity, transcendence, selfreflection and others appeared in different world parts independent of each other. This way of thinking has opened doors to new world religions, sciences, philosophy and arts. At least this way of thinking has constituted a human being as we know him since that period until now. An important center of this cultural revolution was Greco-Roman world. But at the same time similar changing took place in China 
and India. In China this transformation was connected at the first extant with Confucius formed basic principles of renewal morality and religion of Chinese society. In India, a similar role was played by Gautama Buddha [4]. We do not find in philosophy of Jaspers the traces of undervaluation of Indian culture. Though it is worthy to remark that Jaspers stood not so far from Jung because he stated Europe got over one more transformation in Modern Age which has founded contemporary rational (scientific) world view of Europe. Indians like Chinese had not such transformation and so stayed until now at the previous level of evolution. In future these cultures will have to adopt the European way of modern thinking if they do not want to be outdone [5]. We are witnesses of this process today, but we cannot be absolutely sure in this. The history of the European literature and arts of the 20th century show different way, which is possible in aspect of development of interrelationships between East and West.

\section{INDIAN BEADS IN 'DAS GLASPERLENSPIEL' OF HERMANN HESSE: THE ART OF NARRATIVE}

The name of the famous German writer Hermann Hesse is closely associated with India and Indian culture. From his childhood, Hesse was fascinated with India and its culture. Hermann Hesse's grandfather Hermann Hundert lived in India for long time, his mother was born there, and Johannes Hesse, the father of the writer, was a missioner in India. After Hermann Hesse's trip into India in 1911, the culture of this country began to find its wide place in his works: the writer reflected this deep interest to the Orient in his works, and first of all in his famous novels "Siddhartha" (1922) and "Das Glasperlenspiel" (1943), the last one won in 1946 the Nobel Prize. Nevertheless, the prologue and the peculiar sketch to "Das Glasperlenspiel" was the allegorical novel "Journey to the East", which was written in 1931. The term "East" is used here by Hesse in the metaphorical meaning. It is not the geographical notion, as one could think, but the intelligible country of the pure spirituality, beauty and kindness, which is located in the human soul. The political events in Germany in 1914 inspired Hesse to address the German intelligence with calling to keep away from being involved into the nationalistic polemics. The German mass media started the political persecution against him, which worsened the mental health of Hesse: as a result, Joseph Lang, the pupil of Jung, began to treat him and gave him more than one hundred psychological sessions. Both were influenced by the Indian culture: one in direct way and the other - indirectly. It is interesting to note, that the name of the main character of "Das Glasperlenspiel" is also Joseph.

The title of the novel "Siddhartha" coincides with the name of the historical founder of Buddhism. The hero of the novel tries to find the spiritual perfection, rejecting on the way to it from the classical way of knowledge. On the way to his perfection, Siddhartha passes the various stages and phases of knowledge. Firstly, he becomes an ascetic, then, he makes a pilgrimage to Buddha. Afterwards, he started the worldly life with the help of the beautiful and experienced courtesan Kamala, but, in several years, Siddhartha quit the life of the earthy joys and pleasures and became a ferryman, trying to learn the changeful and at the same time constant river, to listen its flowing. This practice of contemplating on the river helps Siddhartha to gain Nirvana at the end of the story [6].

In the novel "Das Glasperlenspiel", the writer realized his ideal of the spiritual life, unifying the whole culture of humanity: the oppositions are harmonized - the West and the East, the Christian mystics and the archetypes of Jung, the Indian philosophy and the Taoist practices are united in the ideal country with an austere order of intellectuals. The name of this country is Castalia (from the Greek Mythology we remember that Castalia is the name of a nymph who was altered by Apollo into a fountain inspiring the genius of poetry). Castalia of Hesse was also dedicated to Muses and has two main missions: the first one is to run boarding schools for young boys, and the second one is to play the Glass Bead Game. Hesse uses in the novel some special methods of concentration, which are peculiar for the Indian tradition. For example, all inhabitants of Castalia should resort regularly to meditations, which represent a sequence of breathing exercises and strong-willed techniques of concentration and remind the classical yogic practices, used with the aim to gain Nirvana. These practices help people to understand that the Truth must be experienced, not taught.

The Indian influence on the novel is manifested in one of three stories of Joseph Knecht, which is named as "Indischer Lebenslauf". The end of the story is the same as of the whole novel - the main hero named Dasa (from Sanskrit "a servant") didn't stay in the life to continue his service but decided to run away to the old yogin, to find shelter in Nirvana and recognize of the world as a great illusion or maya. In some sense, he preferred to go to Castalia. Hesse realized in this story the concept "life is a dream or sleep". The world is presented as a consequence of pictures, images and disillusions. At the moment of 'wakening' of Dasa a reader understands that there is an equivalence between sleep, a dream, a play and maya. Also, he realizes that reality, which can be ever imagined, is a service without any hope and interest. That idea is the most actual for the modern Europe and many artists and intellectuals try to express it through their works.

\section{CONCLUSION}

The brief outline of the reception of the Indian culture by the eminent thinkers and writers of the European Culture of 20 th century shows the various and unpredictable ways of how they could be influenced by the Indian culture. There are numerous cases of such an influence, which demand more deep investigation and clarification. The impact of the Indian traditions into the development of the European Culture is so reach and can be found in some patterns of thinking which aroused only in the 20th century. The play of the real and the illusory, infinite change of points of view, mixing the high and the low - all these things were actual for the European culture of the 20th century - and only the Oriental culture could help to manage with such a new reality of Europe. The "East-West" problem was actual not only for Europe, but also for India, which understood the importance of the dialogue and exchange of the best values 
of Oriental and Occidental cultures earlier then Europe did in 19th-20th centuries. The intellectuals of Bengal Renaissance searched for the ways of integration of India into the world culture and the result of such a consideration is the idea of social westernization of the East and spiritual renovation of the West [9]. We see that the Indian thinkers were absolutely right and Europe began this process in the 20th century and this process of the spiritual renovation didn't yet come to its logical end. The modern world really changes and the meanings of the words "East" and "West" are changing. As W. Halbfass notes, there are many modes of present of the Indian tradition in the Western world academic research, the arts, the literature, popular cults, methods of meditation, sectarian movements, "transpersonal psychology" and so on, but it is rather early to say that we have enough experienced to create a true understanding of each other. "We need not only two but many eyes", this sentence of W.E. Hocking discover the necessity in the multidimensional approach to apprehend the culture of East [10] [11].

\section{REFERENCES}

[1] E. Fromm, Haben oder Sein: Die seelischen Grundlagen einer neuen Gesellschaft, Stuttgart: Deutsche Verlangs-Anstalt 1976, pp. 129-150.

[2] K. G. Jung Jung, What India Can Teach Us, in: K. G. Jung, "Collected Works", vol. 10, Princeton University Press 1970, pp. 525-530.

[3] K. G. Jung Jung, The Dreamlike World of India, in: K. G. Jung, Collected Works, vol. 10, Princeton University Press 1970, pp. 515524.

[4] K. Jaspers, Vom Ursprung und Ziel der Geschichte, Zürich: ArtemisVerlag 1949, pp. 18-24.

[5] Op. cit., pp. 88-97.

[6] H. Hesse, ,Siddhartha', Deutsch Modern Prosa, Sankt Petersburg 2015, - $224 \mathrm{p}$

[7] H. Hesse, Das Glasperlenspiel. Versuch einer Lebensbeschreibung des Magister Ludi Josef Knecht samt Knechts hinterlassenen Schriften, [www.royallib.com].

[8] E. Markovich, Hermann Hesse and his novel „The Glass Bead Game” // Hermann Hesse. Glass Bead Game, Moscow, 1969.

[9] T. Skorokhodova, "East - West" Problem in Social Thought of the Bengal Renaissance // Voprosy Filosofii. 2017, Vol. 12, pp. 147-158.

[10] W. Halbfass, India and Europe. An Essay in Philosophical Understanding", Delhi: Motilal Banarsidas Publishers PVT. LTD, 1990, pp. 160-161.

[11] Op. cit., p. 163. 